\title{
Response of Weed Populations to Tillage, Reduced Herbicide AND Fertilizer Rates in Wheat (Triticum aestivum) Production ${ }^{1}$
}

\author{
Resposta de Populações de Plantas Daninhas ao Plantio e a Taxas Reduzidas de Herbicida e \\ Nitrogênio na Produção de Trigo (Triticum aestivum)
}

ACCIARESI, H.A. ${ }^{2}$, BALBI, H.V. ${ }^{3}$, BRAVO, M.L. ${ }^{3}$ and CHIDICHIMO, H.O. ${ }^{4}$

\begin{abstract}
Field experiments were carried out in 1999 and 2000 to investigate the effects of conventional (CT) and no-tillage (NT) systems, interacting with three herbicide dose levels and three nitrogen $(N)$ levels on weed growth and wheat production of two varieties. There was a higher grain yield for NT system compared with CT in one year. CT weed biomass was lower than from NT weed biomass, in both varieties. No differences on wheat biomass and grain yield were observed between full and reduced herbicide rates. $N$ fertilizer increased wheat biomass and grain yield significantly. Only $N$ medium level had an effect upon weed biomass with respect to non-fertilized plots, while the highest fertilization rate lowered weed biomass. Conventional tillage, reduced herbicide rates and nitrogen fertilization were effective ways of limiting weed production in wheat.
\end{abstract}

Key words: Integrated weed management, low input, Triticum aestivum.

\begin{abstract}
RESUMO - Experimentos foram conduzidos sob condições de campo em 1999 e 2000 a fim de investigar os efeitos dos plantios convencional (PC) e direto (PD), em combinação com três doses de herbicidas e três de nitrogênio $(\mathrm{N})$, no crescimento de plantas daninhas e produção de duas variedades de trigo. Foi observada produção maior de grãos PD, comparado ao PC, durante um ano. A biomassa das plantas daninhas no PC foi menor do que no PD, para as duas variedades. Nenhuma diferença em biomassa e produção de grãos de trigo foi observada entre as doses de herbicida integral e reduzida. $\mathrm{N}$ aumentou a biomassa do trigo e produção de grãos significativamente. Apenas o nível médio de $\mathrm{N}$ teve efeito sobre a biomassa das plantas daninhas em relação à não-aplicação de $\mathrm{N}$, enquanto uma taxa maior de $\mathrm{N}$ diminuiu a biomassa das plantas daninhas. No plantio convencional, doses reduzidas de herbicida e aplicação de $\mathrm{N}$ foram efetivos na limitação do crescimento das plantas daninhas no cultivo de trigo.
\end{abstract}

Palavras-chave: manejo integrado de plantas naninhas, baixo insumo, Triticum aestivum.

\section{INTRODUCTION}

The potential for increased crop yields, soil and water conservation, reduced input costs, and better economic returns has resulted in the increased adoption of conservation tillage
(Buhler et al., 1996). Nevertheless, as tillage is decreased, weed control can become a limiting factor in crop production (Buhler, 1992). FroudWilliams et al. (1983) found weed control problems associated with herbicide selectivity and changes occurring in weed communities.

Recebido para publicação em 13.12.2002 e na forma revisada em 2.4.2003.

2 Professor Assistente. Fac. Cs. Agr. y Ftales. UNLP. CC 31. WAA B 1902. La Plata. Argentina. Comisión Investigaciones Cientificas Provincia de Buenos Aires. CIC. Buenos Aires. Argentina. ${ }^{3}$ Pesquisador Assistente; ${ }^{4}$ Professor. 
Changes in tillage practices can affect weed population dynamics, rendering them dependent upon heavy use of herbicide (Buhler, 1995). Different studies have shown the impact of reducing tillage on the population dynamics of weed species. These include increased populations of perennials, summer annual grasses, biennials, and winter annual species (Buhler 1995). It is important to note that the responses of population dynamics are site specific (Arshad et al., 1995) and depend upon species, location and environment (Thomas \& Frick, 1993).

Conservation tillage is an integral component of integrated weed management (IWM) (Swanton \& Weise, 1991). Despite the increasing interest in IWM as a method of reducing herbicide use, contrasting results have been reported. Kim et al. (1997) found that the use of subnormal herbicide doses (50\%) reduced the grain yield of two wheat varieties by approximately $7 \%$, while the weed biomass increased nearly by $6 \%$. Walker et al. (1998) stated that the seed production of Avena fatua and Phalaris paradoxa was either minimal or prevented with the application of the $25 \%$ herbicide rate when competing with $150 \mathrm{pl} \mathrm{m}^{-2}$ of a barley variety. Moreover, in a two-year study, an average of $85 \%$ wild oat control using half herbicide dose has been reported by Wille et al. (1998).

Fertilizer application is an important management factor in conservation tillage systems. Nevertheless, the effect of fertility on weed communities and weed-crop interactions has been investigated to a lesser extent (O’Donovan et al. 1997). Conflicting results have been reported on the effect of nitrogen (N) fertilizer on crop-weed interaction. Valenti \& Wicks (1992) found that increasing $\mathrm{N}$ rates applied to winter wheat decreased annual grass weed populations and yields. Conversely, in other studies, applications of $\mathrm{N}$ favored Setaria viridis (Peterson \& Nalewaja, 1992) and Avena fatua (Carlson \& Hill, 1986) over wheat. Jørnsgård et al. (1996) found differences in the biomass of individual weed species in both wheat and barley crops with $\mathrm{N}$ fertilizer applications.

Soil tillage, herbicide, fertility and weeds are thus expected to interact strongly in order to have definitive effects on crop growth and yields. Information on the impact of several management techniques, i.e., herbicide rates, fertilizer application and different types of tillage, is needed for developing a reliable IWM.

This study is concerned with effects of two tillage systems and different management inputs of nitrogen $(\mathrm{N})$ fertilizer and herbicide rates on the biomass and yield of wheat varieties and weed biomass.

\section{MATERIALS AND METHODS}

Field experiments were established during 1999 and 2000 at the Experimental Station of La Plata National University $\left(34^{\circ} \mathrm{S}, 58^{\circ} \mathrm{W}\right.$, La Plata, Argentina). Rainfall during the study period (July-December) was $536.9 \mathrm{~mm}$ in 1999 and $708.1 \mathrm{~mm}$ in 2000 (July-December average: $528.5 \mathrm{~mm}$ ). The experiments were arranged in a randomized complete block design with four replications, with the treatments arranged as split-split plots. The whole plot factor consisted of two tillage systems (A). This includes A1: conventional tillage (CT, ploughing-20 cm, disk-harrowing, standard sowing) and A2: no-tillage (NT, herbicides used to control weeds and straw spread with harrows). The same tillage treatments were applied to the same whole plot each year. The subplot factor consisted of three levels of herbicide rates (B). Three doses of metsulfuronmethyl+dicamba (0/0 (0x), 3.0/50 (0.5x) and 6.0/100 (1x) g a.i. $\mathrm{cm}^{-3} \mathrm{ha}^{-1}$, respectively) were applied at the fourth leaf-unfolded stage (Z14, Zadoks et al., 1974). The sub-subplot factor consisted of three $\mathrm{N}$ levels (C). No $\mathrm{N}$ was applied in the low-N treatment areas. Urea fertilizer $(46 \% \mathrm{~N}, \mathrm{w} / \mathrm{w})$ was broadcasted and incorporated at $\mathrm{Z} 14$ stage at rates of $50 \mathrm{~kg}$ and $100 \mathrm{~kg} \mathrm{~N} \mathrm{ha-1}$ year $^{-1}$ as the medium-N and high-N treatment area, respectively. Two wheat cvs (Buck Pronto (B.Pronto) and Klein Dragon (K.Dragon)) were sown at a density of $300 \mathrm{pl} \mathrm{m}^{-2}$.

The major weed species were Chenopodium album, Viola arvensis, Stellaria media, Lamiun amplexicaule, Polygonum convolvulus and Lolium multiflorum. Minor weed species were Anagallis arvensis, Capsella bursa-pastoris and Spergula arvensis. Weed population was harvested from a $0.5 \mathrm{~m}^{2}$ area in each plot (ten samples per each sub-subplot) at Z31 stage 
and their above-ground dry matter (ADM, $\mathrm{g} \mathrm{m}^{-2}$ ) determined. Crop ADM ( $\mathrm{g} \mathrm{m} \mathrm{m}^{2}$ ), at Z31 stage was determined by hand harvesting samples on triplicate 0.5 by $0.5 \mathrm{~m}$ quadrats randomly located in each sub-subplot. Grain yield $\left(\mathrm{g} \mathrm{m}^{-2}\right)$ was measured on five $1 \mathrm{~m}^{2}$ quadrats on each sub-subplot.

ANOVA and LSD mean separation was performed for $\mathrm{p} \leq 0.05$. The analyses were repeated over years and tested for homogeneity of variance and normality of distribution.

\section{RESULTS AND DISCUSSION}

\section{Soil Tillage}

Tillage effects were significant $(\mathrm{p} \leq 0.05)$ for wheat ADM. CT produced significantly $(\mathrm{p} \leq 0.01)$ higher wheat ADM than NT in 2000 but not in 1999 (Figure 1a). The relatively drier spring of the first year could have mainly conditioned the ADM production of crop and weed at CT treatment.

There were opposite trends for grain yield
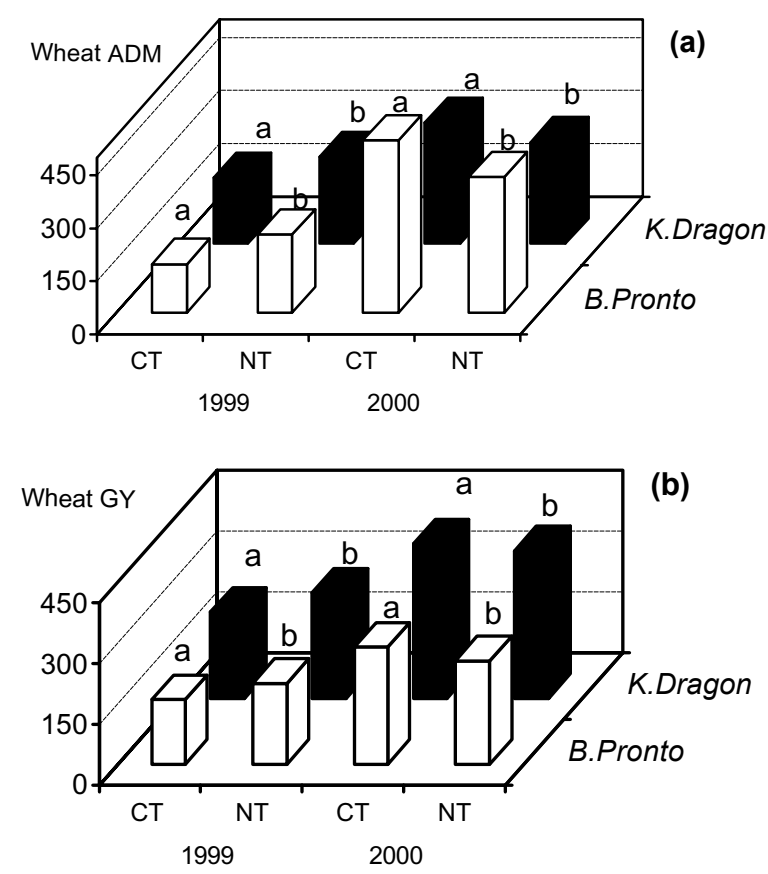

Figure 1 - (a) Wheat above-ground dry matter (ADM, g m ${ }^{-2}$ ) and (b) wheat grain yield (GY, $\mathrm{g} \mathrm{m}^{-2}$ ) under two tillage systems (CT: conventional tillage, NT: No-tillage). Means in a given variety followed by different letters indicate significant differences based on LSD $(p \leq 0.05)$ test. between the two evaluated years. The tillage effects at 1999 resulted in lower crop grain yield under CT plots than NT plots, with lower production in B.Pronto than in K.Dragon (Figure 1b). Conversely, there was a higher grain yield $(\mathrm{p} \leq 0.05)$ for CT than NT plots for the varieties tested in the second year (Figure 1b).

Despite the higher weed ADM registered in K.Dragon, a greater grain yield was obtained, compared with B.Pronto (Figure 1b). These results showed a varietal difference for the effect of both tillage and weed competition. K.Dragon appears as a higher competitive variety than B.Pronto. However, due to the larger weed growth registered at K.Dragon plots, the long-term impact of weed seed return on seed bank dynamics must be examined.

These results are in agreement with Arshad et al. (1995) who found that differences in weed infestation do not always result in significant yield differences. This lack of relation between weed biomass and crop yield could be explained by the occurrence of resources complementarity (no crop-weed competition).

Weed ADM varied across years. Conversely to crop biomass, the main tillage effects in both years were lower weed biomass production under CT in both varieties, and a lower production in 1999 than in 2000 (Figure 2). These results are in agreement with Arshad et al. (1995) who found a higher weed mass in NT than in CT. In no-tillage systems, the weed seeds remain in the upper layer and

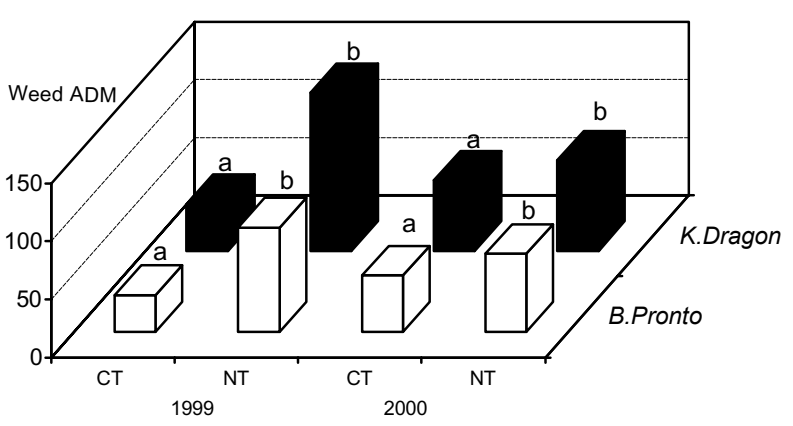

Figure 2 - Weed above-ground dry matter (ADM, $\left.\mathrm{g} \mathrm{m}^{-2}\right)$ under two tillage systems (CT: conventional tillage, NT: Notillage). Means in a given variety followed by different letters indicate significant differences based on LSD $(\mathrm{p} \leq 0.05)$ test. 
immediately contribute to infestation. This could explain the greater biomass registered in NT than in CT plots, despite the relatively drier 1999 spring. However, Buhler (1995) determined that the effect of surface residue on weed dynamics appears to be complex and controlled by interacting factors (soil type, weed species, quality and type of residue, allelopathy, environmental conditions).

\section{Herbicide}

No differences were observed between the effects caused by the $1 \mathrm{x}$ and $0.5 \mathrm{x}$ dose in the crop ADM and grain yield. Conversely, significant differences $(\mathrm{p} \leq 0.05)$ amongst these herbicide rates and $0 x$ were observed for crop variables (Figure 3a, Figure 3b). K.Dragon had higher $(\mathrm{p} \leq 0.05)$ tolerance to weed competition than B.Pronto for the herbicide rates evaluated. This effect was visualised in the 0x plots, where K.Dragon, despite the higher weed ADM obtained (Figure 4), showed a higher grain yield than B.Pronto during both years.
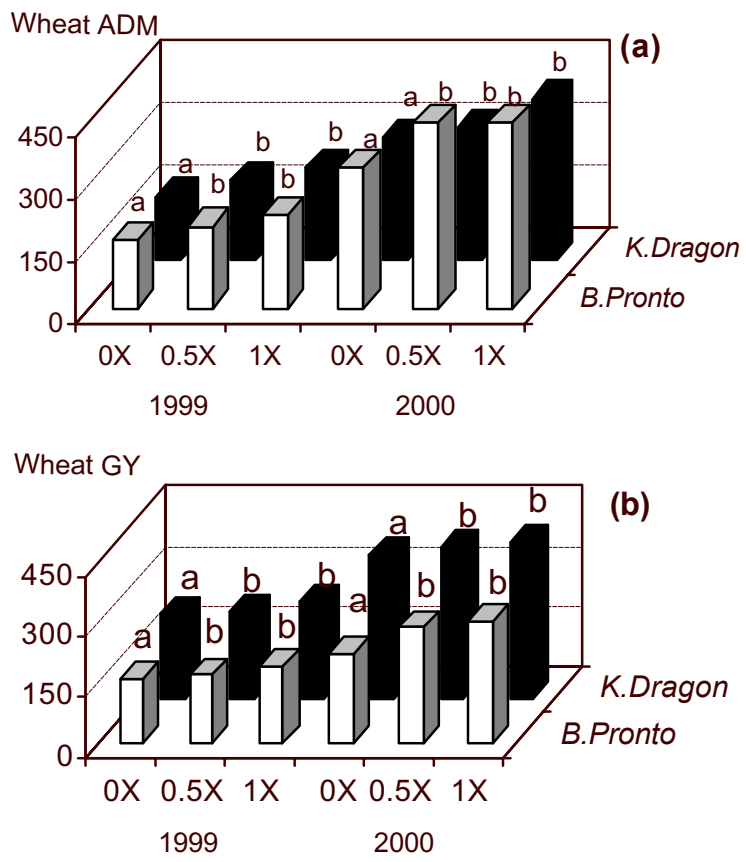

Figure 3 - (a) Above-ground dry matter (ADM, $\mathrm{g} \mathrm{m}^{-2}$ ) and (b) grain yield $\left(\mathrm{GY}, \mathrm{g} \mathrm{m}^{-2}\right)$ of wheat varieties as affected by herbicide rates ( $0 \mathrm{X}$ : no herbicide, $0.5 \mathrm{X}$ : half rate and 1.0X: normal rate). Means in a given variety followed by different letters indicate significant differences based on LSD $(\mathrm{p} \leq 0.05)$ test.

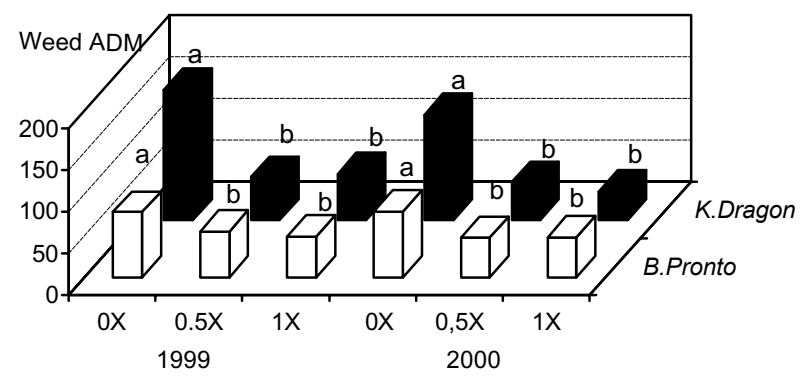

Figure 4 - Weed above-ground dry matter (ADM, $\mathrm{g} \mathrm{m}^{-2}$ ), as affected by herbicide rates ( $0 \mathrm{X}$ : no herbicide, $0.5 \mathrm{X}$ : half rate and 1.0X: normal rate). Means in a given variety followed by different letters indicate significant differences based on LSD $(p \leq 0.05)$ test.

Similarly to crop variables, weed biomass was mostly reduced ( $55 \%$ in both years) by reduced herbicide rates $(0.5 x)$ with no significant differences with 1.0x herbicide rate. Nevertheless, when no herbicide was applied, there were significant differences $(p \leq 0.05)$ between wheat varieties. For both years, a higher weed ADM in K.Dragon plots was obtained (Figure 4). On the other hand, no tillage-herbicide interactions were found. According to these results, herbicides influenced grain yield and weed ADM similarly, irrespective of tillage treatments.

Teasdale et al. (1991) revealed the risk of confounding the effect of tillage with herbicide effects and stated the need to evaluate the direct effects of tillage systems on weed population dynamics over several years of rotation. No significant tillage-herbicide interactions were found here. These results indicate that there is no influence of tillage system on weeds despite herbicide application at reduced doses. Such data tend to indicate that reduced herbicide rates have an adequate fit to the weed flora present in the study, agreeing with the results obtained by Walker et al. (1998).

\section{Fertilization}

For the two years evaluated, $\mathrm{N}$ fertilizer significantly increased wheat ADM and grain yield with differences $(\mathrm{p} \leq 0.05)$ between medium and high level for grain yield. In 1999, a year with a relatively dry spring, a minor effect was obtained (Figure 5a, Figure 5b). 

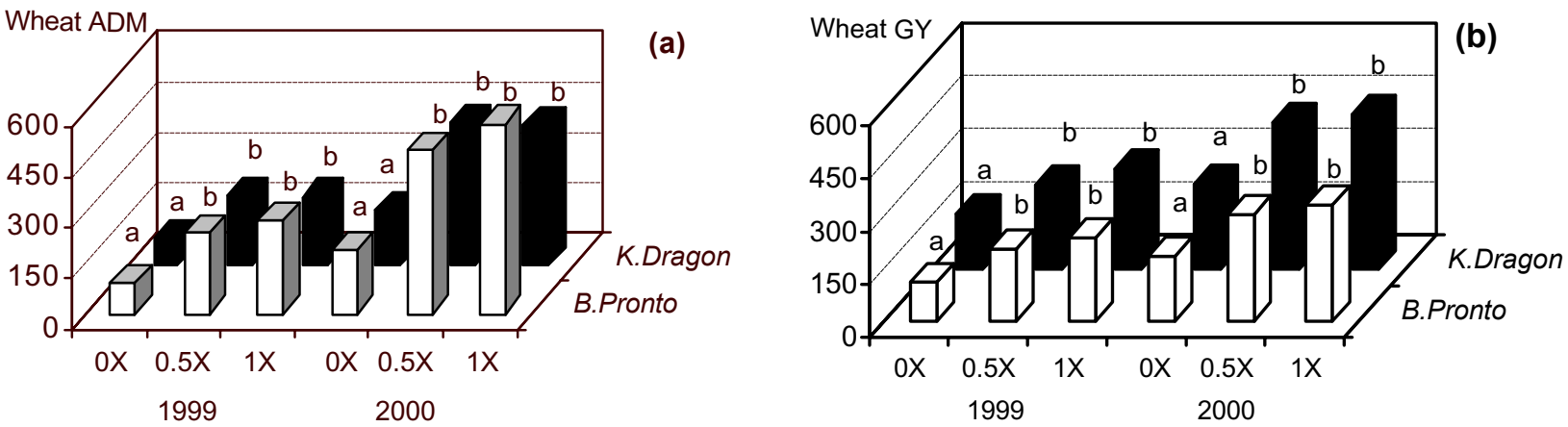

Figure 5 - (a) Above-ground dry matter $\left(\mathrm{ADM}, \mathrm{g} \mathrm{m}^{-2}\right)$ and (b) grain yield $\left(\mathrm{GY}, \mathrm{g} \mathrm{m}^{-2}\right)$ of wheat varieties as affected by fertilizer rates (0N: no fertilizer applied, $50 \mathrm{~N}: 50 \mathrm{~kg} \mathrm{~N} \mathrm{ha}^{-1}$ and $100 \mathrm{~N}$ : $100 \mathrm{~kg} \mathrm{~N} \mathrm{ha} \mathrm{N}^{-1}$. Means in a given variety followed by different letters indicate significant differences based on LSD ( $\mathrm{p} \leq 0.05)$.

No significant tillage-fertilization interaction was obtained at each year for grain yield. A higher yield increase of wheat under no-tillage treatment (NT) in each year $(100 \mathrm{~N}$ : $120 \%$ in $1999,110 \%$ in 2000 ) was registered, compared to conventional tillage (CT, $100 \mathrm{~N}$ : $\sim 70 \%$ both years) (Figure 5a, Figure $5 \mathrm{~b}$ ).

Only at B.Pronto plots a weed ADM increase was obtained when applying moderate $\mathrm{N}$ rates $(50 \mathrm{~N})$ (Figure 6). However, the two fertilization levels significantly lowered weed biomass when competing with K.Dragon (Figure 6). As in the tillage treatment, when nitrogen was added full rate $(100 \mathrm{~N})$ the cvs presented differences in tolerance to competition against weeds. Highest grain yield was obtained by K.Dragon (Figure 5b), despite the higher weed ADM observed in the full rate plots (Figure 6).

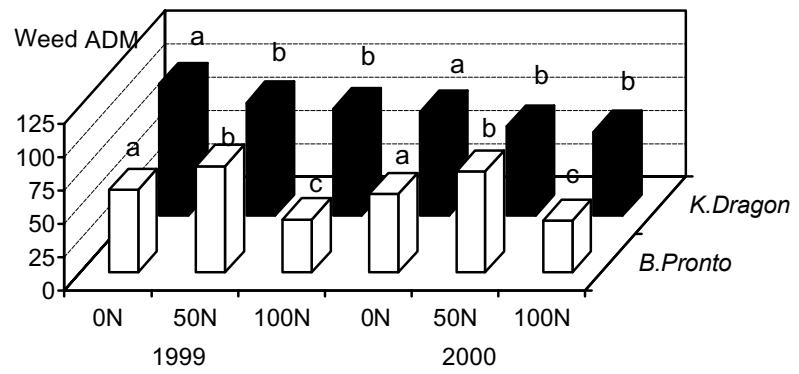

Figure 6 - Weed above-ground dry matter (ADM, $\left.\mathrm{g} \mathrm{m}^{-2}\right)$ as affected by fertilizer rates $(0 \mathrm{~N}$ : no fertilizer applied, $50 \mathrm{~N}$ : $50 \mathrm{~kg} \mathrm{~N} \mathrm{ha}^{-1}$ and $100 \mathrm{~N}$ : $100 \mathrm{~kg} \mathrm{~N} \mathrm{ha}^{-1}$ ). Means in a given variety followed by different letters indicate significant differences based on LSD $(\mathrm{p} \leq 0.05)$ test.
The results indicate that $\mathrm{N}$ optimum rate does not concur for wheat and weed natural populations. These results are in agreement with Valenti \& Wicks (1992), who found that applying $\mathrm{N}$ to winter wheat decreased annual grass weed populations and weed yields, as well as with those obtained by Jørnsgård et al. (1996). These authors found that above dry matter of Chenopodium album, Lamiun amplexicaule, Stellaria media and Veronica spp. cannot be improved with $\mathrm{N}$ application in competition with wheat and barley. Consequently, they concluded that in a low input agriculture, a lower application of $\mathrm{N}$ could favour the increase of such species and a different proportion of them in weed natural populations.

Our results contrast with those reached by Acciaresi et al. (2001), who reported a progressively higher Lolium multiflorum aggressivity with increasing $\mathrm{N}$ rates in competition wheat varieties and with those obtained by Cook \& Clarke (1997). These authors stated that weed number increased with successive use of low herbicides and that weed control was rendered more difficult with the continued use of low $\mathrm{N}$ rates.

These results suggest that variety selection may be an important component to tillage, herbicide and fertilization. Within the conditions tested here, the use of subnormal herbicide doses (50\%) and $\mathrm{N}$ fertilization may be useful in wheat production systems (conventional and no tillage systems) as a strategy to manage natural weed populations. Further information is needed on management

Planta Daninha, Viçosa-MG, v.21, n.1, p.105-110, 2003 
practices to minimize long-term effects on weed dynamics.

\section{LITERATURE CITED}

ACCIARESI, H. A.; CHIDICHIMO, H. O.; SARANDON, S. J. Wheat-Lolium multiflorum competition: effect of nitrogen application onto Argentinean varieties aggressivity. Cereal Res. Comm., v. 29, p. 451-458, 2001.

ARSHAD, M. A.; GILL, K. S.; COY, G. R. Barley, canola and weed growth with decreasing tillage in a cold, semiarid climate. Agron. J., v. 87, p. 49-55, 1995.

BUHLER, D. D. Population dynamics and control of annual weeds in corn (Zea mays) as influenced by tillage systems. Weed Sci., v. 40, p. 241-248, 1992.

BUHLER, D. D. Influence of tillage systems on weed populations dynamics and management in corn and soybean in the central USA. Crop Sci., v. 35, p. 1247-1258, 1995.

BUHLER, D. D.; MESTER, T. C.; KOHLER, K. A. The effect of maize residues and tillage on emergence of Setaria faberi, Abutilon theophrasti, Amaranthus retroflexus and Chenopodium album. Weed Res., v. 36, p. 153-165, 1996.

CARLSON, H. L.; HILL, J. E. Wild oat (Avena fatua) competition with spring wheat: effects of nitrogen fertilization. Weed Sci., v. 34, p. 29-33, 1986.

COOK, S. K.; CLARKE, J. H. The effects of six-years of reduced-rate herbicide use and rotation on weed levels, yields and profitability-TALISMAN results. In: BRIGHTON CROP PROTECTION CONFERENCE,1-3, 1997, Brighton. Proceedings of Brighton Crop Protection Council, 1997. p. 705-710.

FROUD-WILLIAMS, R. J.; DRENNAN, D. S. H.; CHANCELLOR, R. J. Influence of cultivation regime on weed floras of arable cropping systems. J. Appl. Ecol., v. 20, p. 187-197, 1983.

JØRNSGÅRD, B. et al. Influence of nitrogen on competition between cereals and their natural weed populations. Weed Res., v. 36, p. 461-470, 1996.
KIM, D. S. et al. Effects of sub-lethal doses of metsulfuronmethyl on crop-weed competition in two varieties of winter wheat. In: BRIGHTON CROP PROTECTION

CONFERENCE,1-3, 1997, Brighton. Proceedings of

Brighton Crop Protection Council, 1997. p. 669-670.

O'DONOVAN, J. T.; McANDREW, D. W.; THOMAS, G. Tillage and nitrogen influence weed population dynamics in Barley (Hordeum vulgare). Weed Technol., v. 11, p. 502509, 1997.

PETERSON, D. A.; NALEWAJA, J. D. Environment influences green foxtail competition with wheat. Weed Technol., v. 6, p. 607-610, 1992.

SWANTON, C. J.; WEISE, S. F. Integrated weed management in Ontario: the rationale and approach. Weed Technol., v. 5, p. 657-663, 1991.

TEASDALE, J. R.; BESTE, C. E.; POTTS, W. E. Response of weeds to tillage and cover crops residue. Weed Sci., v. 39, p. 195-199, 1991.

THOMAS, A.G. \& FRICK, B.L. Influence of tillage systems on weed abundance in southwestern Ontario. Weed Technol., v.7, p.699-705, 1993.

VALENTI, S. A.; WICKS, G. A. Influence of nitrogen rates and wheat (Triticum aestivum) cultivars on weed control. Weed Sci., v. 40, p. 115-121, 1992.

WALKER, S. R.; ROBINSON, G. R.; MEDD, R. W. Management of wild oats and paradoxa grass with reduced dependence on herbicides. In: AUSTRALIAN AGRONOMY CONFERENCE, 9., 1998, Wagga-Wagga. Proceedings... Wagga-Wagga, Australian Society of Agronomy, 1998. p. 572.

WILLE, M. J.; THILL, D. C.; PRICE W. J. Wild oat (Avena fatua) seed production in spring barley (Hordeum vulgare) is affected by the interaction of wild oat density and herbicide rate. Weed Sci., v. 46, p. 336-343, 1998.

ZADOKS, J. C.; CHANG, T. T.; KONZAK, C. F. A decimal code for the growth stages of cereals. Weed Res., v. 14, p. 415-421, 1974. 